\title{
A Comparative Analysis of Director Tenure in South Africa and Selected International Jurisdictions
}

\author{
Rehana Cassim \\ https://orcid.org/0000-0001-6179-2361 \\ University of South Africa \\ cassir@unisa.ac.za
}

\begin{abstract}
Director tenure attracts attention worldwide and is increasingly being recognised as a crucial element in assessing an external (independent nonexecutive) director's independence. Director tenure has recently come under the spotlight in South Africa. Shareholder activists are expressing disapproval of lengthy tenures of directors serving on boards of listed public companies and exerting pressure on long-serving directors to resign from office. This article examines whether the South African corporate governance principles regulating director tenure are adequate or in need of revision. The article examines further the corporate governance practices in leading jurisdictions such as the United Kingdom, Malaysia, Singapore, Hong Kong, and India that have recently revised their corporate governance practices. It then makes recommendations for enhancing the South African corporate governance approach to director tenure. It also calls on directors to collaborate with shareholders and independent external experts to examine their approach to director tenure and, if circumstances allow, revise the company's memorandum of incorporation to limit directors' tenure or provide for a staggered rotation of directors on the board.
\end{abstract}

Keywords: Director tenure; independent non-executive directors; shareholder approval; disclosure; transparency 


\section{Introduction}

Shareholder activists ${ }^{1}$ suspect that directors lose their independence when serving too long on company boards. 'Director tenure' has become an increasingly controversial topic. Shareholder activists in South Africa are expressing disapproval of lengthy tenures of directors of listed public companies and are exerting pressure on long-serving directors to resign from office. Director tenure requires attention in South Africa, being one of the leading emerging economies in Africa and a potential investment destination. $^{2}$

This article analyses whether the corporate governance practices on director tenure, as embodied in the King IV Report on Corporate Governance for South Africa 2016 ('the King IV Report') $)^{3}$ are adequate or in need of revision. Company boards form the bedrock of corporate governance: The King IV Report ${ }^{4}$ affirmed that the board should be the pivotal point and custodian of corporate governance of a company. The COVID19 global pandemic has highlighted the need for boards to be fit for purpose and able to competently steer the company through unexpected and trying circumstances. ${ }^{5}$ This article focuses on outside or external directors, also known as independent nonexecutive directors. After briefly highlighting the controversy surrounding lengthy director tenures, the article examines the South African corporate governance framework on director tenure and then surveys recent developments in corporate governance codes in Australia, the United Kingdom (UK), Singapore, Malaysia, Hong Kong, and India. These jurisdictions were chosen first, for the fact that their influential corporate governance codes have incorporated recent revisions of the corporate

1 Shareholder activists in this context refer to institutional investors and individual shareholder activists. Institutional investors include large retirement and pension funds, insurance companies, hedge funds and asset managers. They generally have more resources to thoroughly scrutinise the performance of a company than individual shareholders. A recent trend has emerged in South Africa of individual shareholder activists, holding shares in their personal capacity, engaging in shareholder activism. Since it may be difficult for individual shareholder activists to access management directly, they tend to rely on public strategies of shareholder activism, such as raising their concerns at annual general meetings and on various media platforms (see further on individual shareholder activism Suzette Viviers, 'Individual Shareholder Activism in South Africa: The Case of Theo Botha' (2016) 9(2) Journal of Economic and Financial Sciences 353).

2 Organisation for Economic Co-operation and Development, 'Business Insights on Emerging Markets 2020' (OECD Emerging Markets Network, OECD Development Centre) <www.oecd.org/dev/EMnetBusiness-Insights-2020.pdf> accessed 19 April 2021; African Development Bank Group, 'African Economic Outlook 2020: Developing Africa's Workforce for the Future' (7 June 2019) <www.afdb.org/en/documents/african-economic-outlook-2020> accessed 19 April 2021.

3 The King IV Report came into effect on 1 November 2016 and replaced the former King Report on Governance for South Africa 2009 ('the King III Report') in its entirety.

4 See King IV Report, principle 6.

5 Securities Commission Malaysia, Corporate Governance Monitor 2020 (October 2020) 9 <https://www.sc.com.my/api/documentms/download.ashx?id=ff69ce0d-a35e-44d4-996ac591529c56c7> accessed 15 April 2021 ('Malaysia Corporate Governance Monitor 2020'). 
governance best practice recommendations on director tenure and, secondly the company law systems in these jurisdictions, like the South African system, share a unitary board structure with executive and non-executive directors serving together on a single board. ${ }^{6}$ The article then evaluates the South African approach to director tenure and whether it reflects international trends. Finally, recommendations are made for enhancing the South African corporate governance approach to director tenure.

\section{Controversy Surrounding Lengthy Director Tenures}

Scholars disagree about the effect of lengthy director tenures, as studies have revealed divergent results. For example, some studies show that long-tenured directors become friendlier with management over time and lose their ability to monitor the actions of management objectively and critically, thus diminishing the level of board independence. ${ }^{7}$ Empirical studies have shown that board independence ensures better performance by the company, ${ }^{8}$ while some scholars argue that limiting director tenure strengthens director independence and enhances company performance. In contrast, other studies show that long-tenured board members are better positioned to monitor and scrutinise management because they are not as prone to peer pressure, more likely to restrain opportunistic behaviour by management, and less likely to be controlled by management. ${ }^{9}$ Thus, while some studies contend that long-tenured directors have a

6 The unitary board system applies in South Africa, the UK, Malaysia, Singapore, Hong Kong, India, Australia, and several Commonwealth jurisdictions. The United States of America (USA) also applies a unitary board structure, though with some variations. In contrast, a dual board comprises two separate boards: the management (or executive) board and the supervisory board. The latter has representatives of both employees and shareholders and supervises the management board on behalf of shareholders. This structure applies in Germany, China, the Netherlands, and to some extent in France. On the unitary and dual board structures, see further Paul Davies and Sarah Worthington, Gower: Principles of Modern Company Law (10th edn, Sweet \& Maxwell 2016) 387-390 and Ramani Naidoo, Corporate Governance-An Essential Guide for South African Companies (3rd edn, LexisNexis 2016) 461-463.

7 Nikos Vafeas, 'Length of Board Tenure and Outside Director Independence' (2003) 30(7)-(8) Journal of Business Finance and Accounting 1045; Raymond van Ness, Paul Miesing and Jaeyoung Kang, 'Board of Director Composition and Financial Performance in a Sarbanes-Oxley World' (2010) 10(5) Academy of Business and Economics Journal 8; William Libit and Todd Freier, 'Director Tenure: The Next Boardroom Battle' (2015) The Corporate Board 5 <www.chapman.com/media/publication/498_Chapman_Director_Tenure_Next_Boardroom_Battle_ 030415.pdf $>$ accessed 20 April 2021; Yaron Nili, 'The "New Insiders": Rethinking Independent Directors' Tenure' (2016) 68(1) Hastings LJ 118; Nuria Reguera-Alvarado and Francisco Bravo, 'The Effect of Independent Directors' Characteristics on Firm Performance: Tenure and Multiple Directorships' (2017) 41 Research in International Business and Finance 592; Joshua Livnat and others, 'Do Directors have a Use-by Date? Examining the Impact of Director Tenure on Firm Performance' (2019) 19(2) American J of Management 99.

8 See Reguera-Alvarado (n 7) 598 and Steven Petra, 'Do Outside Independent Directors Strengthen Boards?' (2005) 5(1) Corporate Governance 55-64.

9 Van Ness (n 7) 8; David Katz and Laura McIntosh, 'Renewed Focus on Corporate Director Tenure' (2014)

New York

$\mathrm{LJ}$

$(22$

May

2014) 
lower level of independence, other studies contend that these directors may possess a superior ability to evaluate management, thus making them more independent. ${ }^{10}$

It has been argued that imposing director term limits constitutes an arbitrary prevention of shareholders' retaining directors on the board, regardless of whether the company needs their experience and skills. ${ }^{11}$ It is also argued that long-serving directors possess invaluable experience, industry knowledge, and an enhanced understanding of the company's processes and strategies, which newly appointed directors may lack. ${ }^{12}$ For these reasons, it is argued that directors' tenure should not be limited. Conversely, it has been argued that directors' tenure should be limited because studies show that directors become complacent the longer they remain on the board. ${ }^{13}$ It is also argued that limiting the tenure of directors increases board diversity and attracts new perspectives and skills to the board. ${ }^{14}$ Given these two conflicting views about the impact of director tenure on the independence and conduct of directors, perhaps a third view would suggest that the optimal director tenure would vary by industry and company. ${ }^{15}$

Despite the controversy surrounding lengthy director tenure, it is increasingly being regarded as a critical factor in appraising the independence of a non-executive director. The viewpoint that long-serving directors are so enmeshed with the company that they lack independence, resulting in unsatisfactory performance by the company, is gaining traction amongst corporate governance experts and shareholder activists. ${ }^{16}$ There have been rising calls from shareholder activists to 'refresh the board ${ }^{17}$ and to regard boards with several long-serving directors as 'entrenched." ${ }^{18}$ Shareholder activists have increasingly pressurised boards to replace long-serving directors with new appointees.

<www.wlrk.com/webdocs/wlrknew/AttorneyPubs/WLRK.23346.14.pdf> accessed 15 April 2021; Livnat (n 7) 98; Muhammad Umar bin Abdul Razak, Mazlina Mahali and Yang Chik Adam, 'Nine Year Tenure as Independent Director: Overstaying the Welcome?' (2016) 11(6) The Social Sciences 7316.

10 Van Ness (n 7) 9; Libit (n 7) 7; Nili (n 7) 123; Sterling Huang and Gilles Hilary, 'Zombie Board: Director Tenure and Firm Performance' (2018) 56(4) J of Accounting Research 1290.

11 Scott Herlihy, Steven Stokdyk and Joel Trotter, 'Director Tenure: A Solution in Search of a Problem' (2014) <www.lw.com/thoughtLeadership/lw-nacd-director-tenure> accessed 20 April 2021.

12 Vafeas (n 7) 1044; Libit (n 7) 7; Razak (n 9) 7317. Studies suggest that the time needed for newly appointed directors to attain a satisfactory understanding of the company is between five and nine years (Herlihy (n 11); Reguera-Alvarado (n 7) 598; Livnat (n 7) 123).

13 Livnat (n 7) 100.

14 Van Ness (n 7) 9; Libit (n 7) 7.

15 Herlihy (n 11).

16 Nili (n 7) 100; Bursa Malaysia, Corporate Governance Guide Pull-out I: Guidance on Board Leadership and Effectiveness 9 <www.bursamalaysia.com/sites/5bb54be15f36ca0af339077a/assets/5bb54d165f36ca0c341f0065/Pul 1-out_I.PDF> accessed 16 April 2021 ('Malaysia Corporate Governance Guide').

17 See Livnat (n 7) 97.

18 Katz (n 9); Malaysia Corporate Governance Guide (n 16) 82. 


\section{The Framework Governing Director Tenure in South Africa}

The Companies Act 71 of 2008 ('the Companies Act') does not distinguish between executive, non-executive and independent directors. Nor does it limit the number of years for which a director may serve on a board. Under section 68(1) of the Companies Act, a director elected by the shareholders may serve on a board for an indefinite term, or for a term set out in the company's memorandum of incorporation (if any). ${ }^{19}$ Consequently, directors may serve on a board until they resign, are removed from office, or become disqualified from continuing to serve, subject to provisions (if any) in the company's memorandum of incorporation limiting their term or providing for a staggered rotation of board members.

The instruments governing the tenure of independent non-executive directors in South Africa are the King IV Report and the Listings Requirements of the Johannesburg Stock Exchange Limited ('the JSE Listings Requirements') which regulate companies listed on the Johannesburg Stock Exchange Limited (JSE), the leading stock exchange on the African continent. The King IV Report's legal status is that of a set of voluntary principles and practices. ${ }^{20}$ In the event of a conflict between legislation and the King IV Report, legislation will prevail. ${ }^{21}$ So the King IV Report's practices and recommendations are persuasive and not binding for boards of directors, except in the case of listed companies. Listed companies must comply with certain corporate governance practices under paragraph 3.84 of the JSE Listings Requirements. Paragraph 8.63(a) of the JSE Listings Requirements obliges listed public companies to disclose the extent of their implementation of the King IV Report in their annual reports. The purpose of incorporating certain corporate governance practices in the JSE Listings Requirements is to make implementation compulsory for listed companies. ${ }^{22}$

While the application regime of the previous King III Report was that of 'apply or explain,' the King IV Report's regime is 'apply and explain.' The main difference is that in the King IV Report, the principles are phrased as aspirations and ideals fundamental to good governance. Therefore, the application of the principles is assumed. ${ }^{23}$ The explanation provided should address the practice implemented and how its implementation gives effect to the relevant principle. ${ }^{24}$

19 See further on s 68(1) of the Companies Act Rehana Cassim, 'Governance and the Board of Directors' in FHI Cassim and others (eds), Contemporary Company Law (2nd edn, Juta 2012) 126 and JL Yeats and others, Commentary on the Companies Act of 2008 (Revision Service 1 2020, Juta 2018) 2-1257.

20 King IV Report 35.

21 ibid.

22 See JSE Listings Requirements para 3.84.

23 King IV Report 37.

24 ibid. 


\section{Meaning of 'Executive,' 'Non-executive' and 'Independent' Directors}

Principle 7 of the King IV Report recommends that the board is composed of members with the appropriate balance of knowledge, skills, experience, diversity, and independence for it to discharge its governance role and responsibilities objectively and effectively. When determining the size of the board, the appropriate mix of executive, non-executive and independent non-executive directors must be considered. ${ }^{25}$ The King IV Report places much value on including independent directors on the board by recommending that the board should comprise a majority of non-executive directors, most of whom should be independent. ${ }^{26}$

Strangely, the concepts of 'executive' and 'non-executive' directors are not defined in the King IV Report, but they are defined in the JSE Listings Requirements. Paragraph 3.84(e) of the JSE Listings Requirements obliges listed companies to categorise each director's capacity as executive, non-executive or independent. Executive directors (also known as 'inside directors' $)^{27}$ are defined as directors who are involved in the dayto-day management of the company and/or are full-time salaried employees of the company or any of its subsidiaries. ${ }^{28}$ Logically, then, a non-executive director is defined as one who is not involved in the day-to-day management of the business or a full-time salaried employee of the company or any of its subsidiaries. ${ }^{29}$ Non-executive directors play a critical role in providing independent and objective judgment on company matters. ${ }^{30}$ They are not required to give constant attention to the company's affairs, and they perform intermittent duties at board meetings and at other meetings that may require their consideration. ${ }^{31}$ Paragraph 3.84(e)(iii) of the JSE Listings Requirements states that independent directors should be determined holistically, on a substance-overform basis, in accordance with the indicators set out in the King IV Report and section 94(4)(a) $)^{32}$ and (b) of the Companies Act.

'Independence' is defined in the King IV Report as meaning the exercise of objective, unfettered judgment. ${ }^{33}$ Non-executive directors may be categorised by the board as 'independent' if the board concludes 'that there is no interest, position, association or relationship which, when judged from the perspective of a reasonable and informed

25 ibid, principle 7, recommended practice $7 \mathrm{~b}$.

26 ibid, principle 7, recommended practice 8.

27 Protect a Partner (Pty) Ltd v Laura Machaba-Abiodun (2013) 34 ILJ 392 (LC) para 48.

28 JSE Listings Requirements, para 3.84(e)(i).

29 ibid, para 3.84(e)(ii).

30 See King III Report, annex 2.3.

31 Fisheries Development Corporation of SA Ltd v Jorgensen; Fisheries Development Corporation of SA Ltd v AWJ Investments (Pty) Ltd 1980 (4) SA 156 (W) 165; Howard v Herrigel \& Another NNO 1991 (2) SA 660 (A) 678.

32 Under the Companies Act, s 94(4)(a) read with s 94(5), minimum qualification requirements may be prescribed for members of an audit committee by the Minister of Trade and Industry.

33 King IV Report 13. 
third party, is likely to influence unduly or cause bias in decision-making in the best interests' of the company. ${ }^{34}$ The King IV Report sets out certain factors to be considered by the board when assessing a board member's independence for the purposes of this categorisation. ${ }^{35}$ These factors are whether the director:

(i) is a significant provider of capital, or continuous funding to the company, or an officer, employee or representative of such provider;

(ii) takes part in a company's share-based incentive scheme; ${ }^{36}$

(iii) owns shares in the company to a value which is material to his or her personal wealth;

(iv) has been employed by the company as an executive manager during the previous three financial years or is a related party to such executive manager;

(v) has been the designated external auditor responsible for conducting the statutory audit for the company or a vital member of the audit team of the external audit firm during the previous three financial years;

(vi) is a significant or ongoing professional adviser to the company other than as a board member;

(vii) is a member of the board or the executive management of a significant customer or supplier of the company, or of another company which is a related party to the company; or

(viii) is entitled to remuneration that is dependent on the company's performance.

The listed factors must be considered holistically and on a substance-over-form basis. ${ }^{37}$

Even though the Companies Act does not define the terms 'non-executive' or 'independence' in relation to directors, the criteria stipulated in section 94(4)(b) of the Companies Act regarding the eligibility of audit committee members are in accordance with the notion of an independent non-executive director. Section 94(4)(b) of the Companies Act states that a director on the audit committee must not be

(i) involved in the day-to-day management of the company's business or have been so involved during the preceding financial year;

34 ibid, principle 7, recommended practice 27.

35 ibid, principle 7, recommended practice 28 .

36 This requirement is also highlighted by JSE Listings Requirements, para 3.84(e)(iii).

37 King IV Report, principle 7, recommended practice 28. 
(ii) a prescribed officer ${ }^{38}$ or full-time employee of the company or another related or inter-related company, ${ }^{39}$ or have been such an officer or employee during the preceding three financial years; or

(iii) a material supplier or customer of the company such that a reasonable and informed third party would conclude that the integrity, impartiality, or objectivity of that director is compromised by that relationship; or

(iv) a person related ${ }^{40}$ to any of the above persons.

In terms of section 94(2) of the Companies Act, an audit committee must be appointed by a public company, a state-owned company, and any other company required by its memorandum of incorporation to have an audit committee. The committee must also comprise at least three members. It follows that a listed public company (amongst others) must appoint a certain number of independent non-executive directors to serve on its audit committee.

Independent directors' chief role is to improve companies' governance structure by protecting the shareholders' rights and interests and preventing unmonitored control by executive directors, thereby creating an internal check-and-balance system. ${ }^{41}$ Independent directors are expected to be involved in formulating strategies; ensuring compliance with legislation and detecting fraud. ${ }^{42}$ By ensuring external control over executive directors, independent directors play a critical role in avoiding, or at least mitigating, corporate corruption. ${ }^{43}$ A company may be vulnerable to corporate

38 A prescribed officer is a person who exercises general executive control over and management of the whole or a significant portion of the company's business and activities or regularly participates to a material degree in the exercise of general executive control over and management of the whole or a significant portion of the company's business and activities (see Companies Regulations, 2011, reg 38, published under GN R351 (26 April 2011) GG 34239).

39 'Inter-related,' when used in respect of three or more persons, means persons who are related to one another in a linked series of relationships, such that two of the persons are related in a manner contemplated in s 2(1) of the Companies Act, and one of them is related to the third in any such manner, and so forth in an unbroken series (see Companies Act, s 1).

40 Related persons are those who are connected to each other by marriage; living together in a relationship similar to marriage; separated by no more than two degrees of natural or adopted consanguinity or affinity, or in circumstances where an individual directly or indirectly controls a juristic person (Companies Act, s 2(1)).

41 Melinda Vaughn and Lori Ryan, 'Corporate Governance in South Africa: A Bellwether for the Continent?' (2006) 14(5) Corporate Governance: An International Review 508.

42 Scotland Duncan, 'The Empirics of Governance and Fraud' (2009) 70(3) University of Pittsburgh Law Review 485-486; Naidoo (n 6) 143; Tobie Wiese, Corporate Governance in South Africa with International Comparisons (2nd edn, Juta 2017) 32.

43 Madhurrya Arindam, 'The Independent Director: Has it been Indianised Enough?' (2013) 6(2) NUJS LR 234; Devika Nayak, 'Role of Independent Directors - Is Section 149 better than Clause 149? (2013) 2 National Law University Delhi Student LJ 109; Michael Donadelli, Marco Fasan and Barbara Magnanelli, 'The Agency Problem, Financial Performance and Corruption: Country, Industry and 
corruption if the independence of its board is compromised. ${ }^{44}$ Board independence may be compromised by the executive directors individually exercising decision-making powers instead of the board doing so collectively. ${ }^{45}$ A weak internal control and a lack of scrutiny of the conduct of executive directors may entail a concentration of power for executive directors, thus providing them with almost complete autonomy over decisions, which could be used to gain personal benefits and lead to corporate corruption if such directors were unethically inclined. ${ }^{46}$ Independent directors can also play an essential role in strengthening corporate boards and resolving conflicts of interest affecting members of the board. ${ }^{47}$

Independent directors should display independence in appearance (perceived independence) and independence of mind (independence in thought and action). ${ }^{48}$ The Organisation for Economic Co-operation and Development ('OECD') Principles of Corporate Governance ('the OECD Principles of Corporate Governance') are intended to operate as an international reference point for implementing good corporate governance globally. It is noteworthy that these principles emphasise the board's ability to exercise an objective, independent judgment on corporate affairs. ${ }^{49}$ According to these principles, board independence requires that a sufficient number of board members need to be independent of management. ${ }^{50}$ In addition, independent directors

Firm Level Perspectives' (2014) 11 European Management Review 264; Krishna Thej, 'Independent Directors in the Companies Act 2013: An Analysis' (2014) 35(8) Company Lawyer 252; Yaron Nili, 'Out of Sight, Out of Mind: The Case for Improving Director Independence Disclosure' (2017) 43(1) The $\mathrm{J}$ of Corporation L 45.

44 Rebecca Hirsch and Susan Watson, 'The Link between Corporate Governance and Corruption in New Zealand' (2010) 24 New Zealand Universities LR 50.

45 Hirsch (n 44) 50. As was held in Kaimowitz v Delahunt \& Others 2017 (3) SA 201 (WCC) paras 21 and 27 , the overall supervision of the management of a company resides in its board of directors collectively, as opposed to individual directors. See further on this case Rehana Cassim, 'The Right of a Director to Participate in the Management of a Company: Kaimowitz v Delahunt 2017 (3) SA 201 (WCC)' (2018) 30(1) SA Merc LJ 172.

46 Hirsch (n 44) 62; Cindy Schipani, 'The Role of Corporate Governance in Promoting Integrity and Addressing Corruption' (2014) 35(5) Company Lawyer 136.

47 Petra (n 8) 62; Hirsch (n 44) 71. While many studies have found that having independent directors on the board enhances board performance, other studies have not identified such a link. The link between independent directors and board performance is beyond the scope of this article but see further Petra (n 8) 55-64; Margaret McCabe and Margaret Nowak, 'The Independent Director on the Board of Company Directors' (2008) 23(6) Managerial Auditing J 545-566; Frederick Tung, 'The Puzzle of Independent Directors: New Learning' (2011) 91(3) Boston Univ LR 1175-1190. Nevertheless, it is clear that director independence is important in corporate governance codes in numerous jurisdictions which require the board to comprise a certain number of independent non-executive directors.

48 King IV Report 28; Naidoo (n 6) 140; Malaysia Corporate Governance Guide (n 16) 82.

49 Organisation for Economic Co-operation and Development, G20/OECD Principles of Corporate Governance (OECD Publishing, 2015) 50-52. The OECD Principles of Corporate Governance are an international benchmark for policy makers, companies, investors, and other stakeholders worldwide (see the OECD Principles of Corporate Governance 3). ibid 50 . 
may play a key role in instances where the interests of management, the company, and its shareholders may deviate, such as executive remuneration, take-over defences, large acquisitions, audit functions and changes of corporate control. ${ }^{51}$

\section{Tenure of Independent Non-Executive Directors in South Africa}

The King IV Report, in principle 7, recommended practice 29, links the tenure of nonexecutive directors with their independence by stating as follows:

A non-executive member of the governing body ${ }^{52}$ [the board] may continue to serve, in an independent capacity, for longer than nine years if, upon an assessment by the governing body [the board] conducted every year after nine years, it is concluded that the member exercises an objective judgment and there is no interest, position, association or relationship which, when judged from the perspective of a reasonable and informed third party, is likely to influence unduly or cause bias in decision-making.

The King IV Report recommends that boards should implement measures for the periodic, staggered rotation of its members. ${ }^{53}$ The JSE Listings Requirements require at least one-third of the non-executive directors of listed public companies to retire at the company's annual general meeting, but the retiring members may be re-elected provided they are eligible. The board is required to recommend which of such directors are eligible to stand for re-election, taking past performance and contributions into consideration. $^{54}$

Under the King IV Report, the benchmark for a non-executive director's independence is the assessment of a reasonable and informed third party. This benchmark is less stringent than the approach under the King III Report, requiring that where an independent non-executive director's term exceeded nine years, it had to be subject to a 'particularly rigorous review' by the board.$^{55}$ The review had to consider the director's performance, the factors that could affect his or her independence at the time, and the need for refreshing the board. ${ }^{56}$ Although the King IV Report requires the non-executive director's independence to be reviewed after nine years, it does not require a 'rigorous

51 ibid 52.

52 The 'governing body' is defined in the King IV Report as meaning 'the structure that has primary accountability for the governance and the performance of the organisation. Depending on the context, it includes, among others, the board of directors of a company, the board of a retirement fund, the accounting authority of a state-owned company and a municipal council' (King IV Report, Glossary of Terms, at 12).

53 King IV Report, principle 7, recommended practice 12.

54 JSE Listings Requirements, sch 10, para 10.16(g).

55 King III Report, principle 2.18, recommended practice 77.

56 ibid. 
review' to be conducted, nor does it require the performance of the particular director to be reviewed.

Boards must disclose whether they categorise each non-executive director as independent ${ }^{57}$ as well as each director's period of service on the board. ${ }^{58}$ Non-executive directors on South African boards may qualify to be classified as independent directors for longer than nine years should the board come to a decision on an annual basis that they are independent. No cap is imposed on the tenure of independent non-executive directors. When a non-executive director has been a board member for longer than nine years, a 'summary' of the board's views on such director's independence must be disclosed..$^{59}$

A South African study found that the percentage of companies where the average board tenure was less than nine years, decreased from eighty-nine per cent in 2011 to seventyseven per cent in $2017 .{ }^{60}$ It was also found that in South Africa, directors in the consumer services sector had the highest average tenure ( 8.32 years), followed by those in the industrials sector (7.86 years) and the consumer goods sector (7.32 years). ${ }^{61}$ Another study found that, as at November 2019, the number of non-executive directors serving on the boards of South African active companies listed on the JSE was $2224,{ }^{62}$ with an average tenure of around four years. ${ }^{63}$ It is noteworthy that twenty-seven per cent of these non-executive directors had served on their boards for nine years or longer. ${ }^{64}$

It has been found that some independent non-executive directors have served on the boards of South African listed public companies for as long as forty-six years. The issue of extended director tenure has made South African news headlines recently when at least eight directors of Comair Limited ('Comair') resigned. Comair is South Africa's only JSE-listed airline operator. ${ }^{65}$ At least four of these directors' departure had been linked to concerns about their independence, as expressed by shareholder activists. Shareholders raised challenging questions at Comair's annual general meeting held in

57 King IV Report, principle 7, recommended practice 30d.

58 ibid, recommended practice 30 f.

59 ibid, recommended practice $30 \mathrm{~d}$.

60 Suzette Viviers and others, 'What Study Reveals about Board Independence at SA's Top Firms' (Business Day, 30 January 2020) <https://www.pressreader.com/south-africa/businessday/20200130/281895890220355> accessed 19 April 2021; also available at Suzette Viviers and others, 'News - Study Focuses on Board Independence at SA's Top Firms' (Stellenbosch University) <http://www.sun.ac.za/english/Lists/news/DispForm.aspx?ID=7068> accessed 19 April 2021.

61 ibid.

62 PricewaterhouseCoopers, Non-executive Directors: Practices and Fees Trend Report 25 (13 edn, PWC February 2020) <https://www.pwc.co.za/en/assets/pdf/ned-report-2020.pdf> accessed 19 April 2021.

63 ibid.

64 ibid.

65 Comair operates its own airline (kulula.com) in South Africa in addition to British Airways in South Africa as part of a licence agreement. 
October 2019 on the long tenure of some independent non-executive directors, and whether this might have led to a compromise of the board's independence. ${ }^{66}$ Shareholders questioned the independence of four independent non-executive directors who had respectively served on the board for twenty-five, thirty-nine, forty, and fortysix years. ${ }^{67}$ Shortly after the annual general meeting, and owing to pressure from shareholders who demanded a 'board shake-up,' some of Comair's long-serving directors resigned, and Comair had to replace them with independent directors. ${ }^{68}$

\section{Director Tenure in Selected International Jurisdictions}

It is useful to examine the corporate governance recommendations on director tenure in some influential international jurisdictions, particularly those having recently revised their corporate governance codes. The approach adopted in international jurisdictions may be divided into three categories:

- jurisdictions without a limit on director tenure;

- jurisdictions placing a hard limit on director tenure; and

- jurisdictions implementing measures to be followed, after director tenure has exceeded a certain number of years.

\section{Jurisdictions Without a Limit on Director Tenure}

At one end of the spectrum, certain jurisdictions do not impose any limits on independent non-executive directors' tenure. For example, there are no over-arching regulations or listing standard requirements in the USA that limit the tenure of independent non-executive directors of public companies. ${ }^{69}$ Institutional Shareholder Services, which provides voting recommendations for shareholders' meetings of listed public companies in the USA, recommends that shareholders vote against proposals to limit non-executive directors' tenure through term limits. ${ }^{70}$ Setting term limits for

66 Siseko Njobeni, 'New Blood for Comair Board after Shareholder Outcry' (Business Day, 21 January 2020) <https://headtopics.com/za/new-blood-for-comair-board-after-shareholder-outcry-10826996> accessed 16 April 2021.

67 Ray Mahlaka, 'Comair Comes under Fire for Corporate Governance Mess' (Business Maverick, 16 January 2020) <www.dailymaverick.co.za/article/2020-01-16-comair-comes-under-fire-forcorporate-governance-mess/.air> accessed 16 April 2021.

68 Alistair Anderson, 'Comair Chair Leaves Board After 46 Years' (Business Day, 9 January 2020) $<$ https://www.businesslive.co.za/bd/companies/transport-and-tourism/2020-01-09-comair-chairleaves-board-after-46-years/> accessed 16 April 2021.

69 Libit (n 7) 8; Darren Rosenblum and Yaron Nili, 'Board Diversity by Term Limits' (2019) 71(1) Alabama LR 219.

70 Institutional Shareholder Services Inc., United States Proxy Voting Guidelines: Benchmark Policy Recommendations Effective for Meetings on or after February 12020 (2019) 17 <www.issgovernance.com/file/policy/active/americas/US-Voting-Guidelines.pdf> accessed 15 April 2021 ('US Proxy Voting Guidelines'). 
directors in the USA is rare. ${ }^{71}$ For example, only five per cent of the boards of S\&P 500 companies $^{72}$ in the USA set express term limits for non-executive directors, with the terms varying from ten to twenty years. ${ }^{73}$ Sixty-five per cent of boards state in their corporate governance guidelines that they do not impose any term limits, while thirty per cent fail to even mention term limits. ${ }^{74}$

Even though it does not support imposing term limits, Institutional Shareholder Services still recommends that shareholders scrutinise those boards where the average tenure of all directors exceeds fifteen years. The scrutiny would focus on directors' independence from management and the sufficiency of the turnover, to make sure that fresh perspectives are being introduced to the board. ${ }^{75}$ In the USA, the average tenure of independent directors of S\&P 500 companies in 2019 was eight years (a slight decrease from 8.4 years in 2014), but the longest average board tenure was thirty-five years. ${ }^{76}$ The longest-serving director has served for fifty years. ${ }^{77}$

\section{Jurisdictions Placing a Hard Limit on Director Tenure}

In contrast to the US, the European Commission imposes a hard limit on director tenure. It recommends that companies based in the European Union limit non-executive directors' tenure to twelve years. ${ }^{78}$ While this recommendation has not been widely adopted by European Union member states, ${ }^{79}$ it has been adopted by France. Section 9.5.6 of the Afep-Medef Corporate Governance Code of Listed Corporations ${ }^{80}$ in France states that a particular criterion for a director to be considered independent, is that he or

71 Rosenblum (n 69) 219.

72 Standard \& Poor's 500 Index is a market-capitalisation-weighted index of the 500 largest US publicly traded companies.

73 Spencer Stuart, '2019 U.S. Spencer Stuart Board Index' (Spencer Stuart, 2019) 18 <https://www.spencerstuart.com/-/media/2019/ssbi-2019/us_board_index_2019.pdf> accessed 15 April 2021 ('2019 US Spencer Stuart Board Index’).

74 ibid.

75 US Proxy Voting Guidelines (n 70) 17.

76 '2019 US Spencer Stuart Board Index' (n 73) 16.

77 ibid.

78 Official Journal of the European Union, 'Commission Recommendation of 15 February 2005 on the role of non-executive or supervisory directors of listed companies and on the committees of the (supervisory) board (2005/162/EC)', annex II, s 1(h).

79 See further Katz (n 9).

80 Corporate governance rules in France are mostly set out in statutory provisions in the French Commercial Code and in recommendations in corporate governance codes (for example the French Association of Private Enterprises (Afep)-Movement of French Enterprises (Medef) Code), or in positions expressed by professional bodies and associations. Most large, listed companies in France choose to use the Afep-Medef Corporate Governance Code of Listed Corporations (see Didier Martin, 'France' in Willem Kalkoen (ed), The Corporate Governance Review (10th edn, Law Business Research Ltd 2020) 75). 
she should not have been a director of the corporation for more than twelve years. Once this period ends, a director loses the status of an independent director. ${ }^{81}$

\section{Jurisdictions Implementing Measures to be Followed after Director Tenure Exceeds a Certain Number of Years}

In the middle of the spectrum between the above two categories is a third, according to which certain jurisdictions recommend a limit on director tenure which may be extended if specific measures are implemented. Examples of jurisdictions in this category are Australia, the UK, Malaysia, Singapore, Hong Kong, and India.

A key feature of companies in Malaysia, ${ }^{82}$ Singapore, ${ }^{83}$ Hong Kong $^{84}$ and India ${ }^{85}$ is that many of them are family-owned ${ }^{86}$ with family members often collectively holding large controlling blocks of shares in the companies. ${ }^{87}$ They generally own and manage the

81 Afep-Medef Corporate Governance Code of Listed Corporations, s 9.5.6 (updated in January 2020).

82 Kamini Singham, 'Corporate Governance in Malaysia' (2003) 15(1) Bond LR 318; Mahmoud Rajablu, 'Corporate Governance: A Conscious Approach for Asia and Emerging Economies' (2016) 58(3) Intl $\mathrm{J}$ of $\mathrm{L}$ and Management 324.

83 Tan Lay Hong, 'Family-Owned Firms in Singapore: Legal Strategies for Constraining Self-Dealing in Concentrated Ownership Structures' (2011) 23 Singapore Academy of LJ 892; Yaru Chia, 'Board Diversity in Singapore' (2015) 27(2) Singapore Academy of LJ 325; Dan Puchniak and Luh Luh Lan, 'Independent Directors in Singapore: Puzzling Compliance requiring Explanation' (2017) 65(2) The American J of Comp L 296.

84 Most listed companies on the Stock Exchange of Hong Kong are either family-owned or state-owned (see Alex Lau and others, 'In Search of Good Governance for Asian Family Listed Companies; A Case Study on Hong Kong' (2007) 28(10) Company Lawyer 308; Rajablu (n 82) 324 and Carlyle Wai-ling, Guide for Independent Non-Executive Directors' (6th edn, The Hong Kong Institute of Directors 2021) 5).

85 Many large firms in India are characterised by the presence of a large controlling shareholder, which is either a business family or the state, with the balance of the shares being dispersed amongst a wide body of smaller shareholders. Thus, many companies in India are dominated by promoters who are family members or controlling shareholders (Umakanth Varottil, 'Evolution and Effectiveness of Independent Directors in Indian Corporate Governance' (2010) 6 Hastings Business LJ 287; Arindam (n 43) 233 and 236; RL Manogna and Aswini Kumar Mishra, 'Exploring the Role of Family Ownership in Internationalization: Empirical Investigation of Indian Firms' (2021) 31(1) Review of International Business and Strategy 2).

86 There is no singular definition of a family-owned business, but relevant criteria, according to the Family Business Association of Southern Africa (FABASA), are the following: (i) the majority shareholding belongs to the family; (ii) the family controls strategic business decisions; and (iii) the family has the intention to preserve the business for future generations (FABASA <https://fabasa.co.za/about/> accessed 19 April 2021). For a detailed discussion of the various structures and types of family-owned businesses, see Hong (n 83) 890-892.

87 For example, it was found that at least half of the listed companies in Asian markets are family-owned companies (except for Japan) and that on average, the five largest shareholders in family firms in Singapore control a 65.9 per cent stake in the company, with 38.3 per cent being held by family members (see Puchniak (n 83) 297). 
company and are thus both directors and substantial shareholders. ${ }^{88}$ The boards of family-controlled companies are frequently dominated by family members, who tend to use their controlling powers to control the board and entrench themselves in their positions. ${ }^{89}$ The average tenure of family-member directors in such family-owned companies is usually much longer than that of non-family members. ${ }^{90}$ Due to the concentrated ownership structures in family-owned companies, an important corporate governance concern is the expropriation of minority shareholders' rights by the controlling shareholders. ${ }^{91}$ In contrast, in South Africa family-owned companies are not as prevalent, although they are rapidly growing. ${ }^{92}$

The discussion turns to the approaches in these six jurisdictions.

\section{Australia}

Australia does not impose a hard limit on independent non-executive directors' tenure, but it does link director tenure to the director's independence. The Australian Stock Exchange (ASX) Corporate Governance Council's proposal to impose a nine-year term limit was recently rejected. ${ }^{93}$ The relevant commentary explains the rejection:

The mere fact that a director has served on a board for a substantial period does not mean that the director has become too close to management or a substantial holder to be considered independent. ${ }^{94}$

Nevertheless, the ASX Corporate Governance Principles state that the board should, on a regular basis, evaluate whether a director who has served on the board for more than ten years has become too close to management or a substantial shareholder to be

88 Lau (n 84) 306.

89 Varottil (n 85) 286; Arindam (n 43) 236; Puchniak (n 83) 297.

90 For example, a study found that the average tenure of family-member directors in family-owned companies in Singapore was 20.7 years for founder family members and 15.7 years for other family members, as opposed to 7.5 years for nonfamily-member directors (see Puchniak (n 83) 297).

91 Singham (n 82) 318; Varottil (n 85) 290; Arindam (n 43) 237; Chia (n 83) 308.

92 Thea Visser and Evelyn Chiloane-Tsoka, 'An Exploration into Family Business and SMEs in South Africa' (2014) 12(4) Problems and Perspectives in Management 428). There is no reliable database pertaining to family-owned businesses in South Africa. Examples of listed family-owned businesses in South Africa are Remgro Ltd and Pick 'n Pay Stores Ltd.

93 See further Razak (n 9) 7314.

94 See ASX Corporate Governance Council, Corporate Governance Principles and Recommendations (4 edn, February 2019), commentary to recommendation 2.3 ('ASX Corporate Governance Principles'). 
considered independent. ${ }^{95}$ Thus, after a director has served for a period of more than ten years, the board is required to assess his or her independence on a regular basis.

\section{United Kingdom}

The UK Corporate Governance Code of 2018 ('UK Corporate Governance Code') ${ }^{96}$ states that one of the circumstances which are likely to impair a non-executive director's independence, or could appear to impair it, is board service for longer than nine years. ${ }^{97}$ A discretion is conferred on the board to consider a non-executive director to be independent even if he or she has been a board member for longer than nine years, as long as a clear explanation for such reasons is provided. ${ }^{98}$

In its Guidance on Board Effectiveness ('the UK Guidance on Board Effectiveness'), ${ }^{99}$ the Financial Reporting Council recommends that the tenure of non-executive directors should be considered during the entire duration of their tenure to ensure that they continue to show that they are holding management accountable. ${ }^{100}$ It states further that board refreshment should be discussed with the company's shareholders. ${ }^{101}$

There is a more stringent approach in the UK for listed companies with a controlling shareholder ${ }^{102}$ on the London Stock Exchange. These companies must elect or re-elect an independent director, regardless of tenure, through a two-tier voting process by which the election or re-election must be approved by a separate ordinary resolution of the

95 ibid. The average tenure of non-executive directors of the top 200 ASX companies is just under six years (see Egan Associates, 'Director Tenure: How Long is too Long?' (16 May 2020) <https://eganassociates.com.au/board-tenure-how-long-is-too-long/?> accessed 15 April 2021).

The UK Corporate Governance Code is based on a 'comply or explain' approach and applies to all companies with a premium listing, whether incorporated in the UK or elsewhere (UK Corporate Governance Code at 1 and 3).

97 UK Corporate Governance Code, provision 10.

98 ibid.

99 The UK Guidance on Board Effectiveness (July 2018) is one of a series of guidance notes issued by the Financial Reporting Council to aid companies in the UK to apply the principles of the UK Corporate Governance Code.

100 The UK Guidance on Board Effectiveness para 103.

$101 \mathrm{ibid}$, para 98. The average tenure of non-executive directors in the UK in 2019 was 4.1 years (Spencer Stuart, 2019 UK Spencer Stuart Board Index (Spencer Stuart, 2019) 28 <https://www.spencerstuart.com/-/media/2019/ukbi-2019/uk_board_index_2019_final_version.pdf> accessed 15 April 2021.

102 Subject to certain voting rights that are disregarded, a controlling shareholder is a person who exercises controls on their own or together with any person with whom they are acting in concert thirty per cent or more of the votes able to be cast on all or substantially all matters at general meetings of the company (Financial Conduct Authority Listing Rules, Release 6, April 2021, app 1) ('FCA Listing Rules'). Where a listed company has a controlling shareholder, it must have in place a constitution that allows the election and re-election of independent directors to be conducted in accordance with the FCA Listing Rule r 9.2.2.2ER and 9.2.2FR (see FCA Listing Rules, r 9.2.2ADR). 
shareholders as a whole and the independent shareholders ${ }^{103}$ of the listed company in separate tiers. ${ }^{104}$ For an independent non-executive director to remain on the board of a listed company with a controlling shareholder, the resolution approving his or her reelection must be approved by both sets of shareholders. Should there be a conflict between the results of the two votes and approval is not obtained, but the company still wishes to put forward that person for re-election as an independent director, the subsequent re-election must be approved as a single vote by a simple majority of all the shareholders (including the controlling shareholder). ${ }^{105}$ The re-election must be conducted at least ninety days, but not more than 120 days after the original vote. ${ }^{106}$ The dual-voting structure is intended to give the independent shareholders a separate and stronger voice in the election of independent directors. ${ }^{107}$

\section{Malaysia}

The Securities Commission Malaysia issued the Malaysian Code on Corporate Governance 2021 ('MCCG 2021') in April 2021, introducing significant corporate governance developments in Malaysia. ${ }^{108}$ Previously, the Malaysian Code on Corporate Governance 2012 discouraged an independent director from being a board member for longer than nine years, by recommending that his or her tenure should not exceed a cumulative term of nine years. ${ }^{109}$ Of concern in Malaysia is that in certain instances an independent director is replaced by a family member at the end of his or her tenure, a scenario termed as 'independence can be inherited. ${ }^{110}$ This casts doubt on the director's ability to exercise an objective judgment, since such directors usually have a sense of

103 An independent shareholder is a person entitled to vote on the election of directors of a listed company that is not a controlling shareholder of the listed company (FCA Listing Rules, app 1).

104 FCA Listing Rules, r 9.2.2ER.

105 ibid, r 9.2.2FR.

106 ibid.

107 Roger Barker and Iris Chiu, 'Protecting Minority Shareholders in Block-controlled Companies: Evaluating the UK's Enhanced Listing Regime in Comparison with Investor Protection Regimes in New York and Hong Kong' (2015) 10(1) Capital Markets LJ 107; Bobby Reddy, 'The Fat Controller: Slimming down the Excesses of Controlling Shareholders in UK Listed Companies' (2018) 38(4) Oxford J of Legal Studies 747.

108 The MCCG 2021 is effective from 28 April 2021. The first group of companies to commence reporting on their adoption of the practices in MCCG 2021 are those with financial years ending on 31 December 2021 (Securities Commission Malaysia, 'SC Updates the Malaysia Code on Corporate Governance to Promote Board Leadership and Oversight of Sustainability' (Media Releases, 28 April 2021) $<$ https://www.sc.com.my/resources/media/media-release/sc-updates-the-malaysian-code-oncorporate-governance-to-promote-board-leadership-and-oversight-of-sustainability> accessed 2 May 2021) ('SC Media Release'). The approach adopted in the MCCG 2021 is that of 'comprehend, apply and report' (MCCG 2021 para 3.1). Under this approach, companies must understand the spirit and intention behind the principles and practices, implement the practices in substance, and provide a fair and meaningful disclosure on the company's corporate governance practices.

109 Malaysian Code on Corporate Governance 2012, principle 3, recommendation 3.2.

110 Malaysia Corporate Governance Guide (n 16) 86. 
loyalty to the controlling shareholders or the directors who have nominated them. ${ }^{111}$ Owing to a growing concern by stakeholders over the potential negative effect of directors' prolonged tenure on their independence and the potential erosion of the board's objectivity due to familiarity, the MCCG 2017 tightened director tenure provisions to promote directors' independence and objectivity, and the MCCG 2021 further tightened these provisions. ${ }^{112}$

Principle A, Practice 5.3 of the MCCG 2021 calls for a board to limit an independent director's tenure to nine years. Practice 5.4 recommends that a board should have a policy that limits its directors' tenure to nine years without further extension. After that, an independent director may sit on the board but only as a non-independent director. ${ }^{113}$ Should the board still wish to keep an independent director on the board after nine years, it should provide justification and seek the approval of shareholders at an annual general meeting through a two-tier voting process: tier one by large shareholders, ${ }^{114}$ and tier two by the other shareholders. ${ }^{115}$ The resolution will be successful if both tiers support it. ${ }^{116}$ With regard to the justification to retain an independent director on the board beyond nine years, the board should carry out a rigorous review to assess whether the director's independence had been impaired, and disclose the results to the shareholders so that they may make an informed decision. ${ }^{117}$

Under the MCCG 2017, the approval of shareholders through a two-tier voting process was required if the board wished to retain an independent director for longer than twelve years, ${ }^{118}$ but the MCCG 2021 now requires the two-tier voting approval after nine years. ${ }^{119}$ The Malaysian Stock Exchange intends introducing in the listing requirements a twelve-year tenure limit without further extension for independent directors, in due

111 ibid.

112 Malaysia Corporate Governance Guide (n 16) 10; Guidance to Practice 4.2 of the MCCG 2017; MCCG 2021, para G5.3. According to the Securities Commission Malaysia, as at 31 March 2021, 432 independent directors had tenures of more than twelve years, out of which forty-nine independent directors had served on the same board for longer than twenty years (SC Media Release (n 108). Further information is available in Malaysia Corporate Governance Monitor 2020 (n 5).

113 MCCG 2021, principle A, practice 5.3.

114 A large shareholder is a person who is entitled to exercise or control the exercise of thirty-three per cent of the voting shares in the company; is the largest shareholder of voting shares in the company; has the power to appoint or cause to be appointed the majority of the company's directors; or has the power to make or cause to be made, decisions in respect of the business or administration of the company, and to give effect to such decisions or cause them to be given effect to (MCCG 2021, G5.3).

115 MCCG 2021, para G5.3. The two-tier voting process applies to resolutions tabled at general meetings held on or after 2 January 2022 (SC Media Release (n 108)).

116 If there is more than one large shareholder, a simple majority of votes will determine the outcome of the vote on the first tier. The resolution is defeated where the vote between the two tiers differs or where the first-tier voters abstained from voting (MCCG 2021, para G5.3).

117 MCCG 2021, para G5.3.

118 MCCG 2017, guidance to practice 4.2.

119 MCCG 2021, para G5.3. 
course. ${ }^{120}$ The two-tier vote structure is beneficial, in that it serves as a reminder for the board and the shareholders to evaluate prudently the retention of the director, assess any impairment in the director's objectivity, and consider refreshing the board's composition. ${ }^{121}$ Moreover, it provides minority shareholders with an opportunity to vote against the retention of a director in a two-tier voting process, empowering them with a greater voice, ${ }^{122}$ particularly in instances where controlling shareholders may wish to entrench certain directors on the board for long periods.

\section{Singapore}

Singapore has been ranked as a country with the best corporate governance performance globally, ${ }^{123}$ thus its Code of Corporate Governance offers useful lessons on director tenure. Singapore released a new Code of Corporate Governance in August 2018 ('the Singapore Code of Corporate Governance 2018'), ${ }^{124}$ which came into effect from 1 January 2019.

Provision 2.4 of the former Singapore Code of Corporate Governance 2012 stated that the independence of a director who served on the board for longer than nine years was

120 See SC Media Release (n 108).

121 ibid; Malaysia Corporate Governance Monitor 2020 (n 5) 33.

122 Malaysia Corporate Governance Guide (n 16) 88; SC Media Release (n 108).

123 Singapore was ranked first out of 130 countries and territories globally in the corporate governance category of the 2019 'FM Global Resilience Index,' which ranks countries based on the overall resilience of their business environments (see FM Global, '2020 FM Global Resilience Index' <https://www.fmglobal.com/research-and-resources/tools-and-resources/resilienceindex> accessed 16 April 2021). The index has attributed Singapore's leading status in corporate governance to its reliable auditing and accounting standards, regulations, and shareholder governance (see Gabriel Olano, 'Singapore Tops Corporate Governance in FM Global Resilience Index' (Insurance Business Asia, 22 May 2019) <https://www.insurancebusinessmag.com/asia/news/breaking-news/singaporetops-corporate-governance-in-fm-global-resilience-index-167891.aspx > accessed 16 April 2021; Ranamita Chakraborty, 'Singapore Acquires Top Ranking in Corporate Governance Globally' (Asia Insurance Review, 22 May 2019) <www.asiainsurancereview.com/News/View-NewsLetterArticle/id/46863/Type/eDaily/Singapore-acquires-top-ranking-in-corporate-governance-globally\#> accessed 16 April 2021). In 2020 Singapore ranked twenty-second out of 130 in the 2020 FM Global Resilience Index (see FM Global SG | Newsroom, 'High-Ranking Countries in 2020 FM Global Resilience Index Well Positioned to Foster Post-Pandemic Business Recovery' (16 May 2020) $<$ https://newsroom.fmglobal.sg/releases/high-ranking-countries-in-2020-fm-global-resilience-indexwell-positioned-to-foster-post-pandemic-business-recovery> accessed 16 April 2021). By way of comparison, the UK ranked thirteenth; Hong Kong ranked nineteenth; Malaysia ranked forty-first; South Africa ranked forty-seventh; and India ranked fifty-eighth. See further Joyce Koh and Annabelle Yip, 'The Evolution of Corporate Governance in Singapore' (2016) $<$ www.sid.org.sg//images/PDFS/Publications/BoardroomMatters/Vii/1.\%20Boardroom\%20Matters $\% 20$ Vol $\% 20$ II-The $\% 20$ Evolution $\% 20$ Of\%20Corporate\%20Governance\%20In\%20Singapore.pdf> accessed 19 April 2021.

124 The Singapore Code of Corporate Governance 2018 applies to listed companies in Singapore on a 'comply or explain' basis (see para 2). 
to be subject to a particularly rigorous review, and that the board had to explain why this director was to be regarded as independent. This provision has now been tightened still further in provision 2.1 of the Singapore Code of Corporate Governance 2018. ${ }^{125} \mathrm{It}$ now states that when an independent director has served on the board for an aggregate period of more than nine years, his or her tenure as an independent director is subject to a two-tier vote. This vote requires approval by separate resolutions of the majority of: (i) all shareholders; and (ii) all shareholders, excluding shareholders who also serve as directors or the chief executive officer of the company, and their associates. An associate is the person's immediate family, trustees of a trust of which the person or his or her immediate family is a beneficiary, or a company in which the person and his or her immediate family together have an interest of thirty per cent or more. ${ }^{126}$

This requirement will be phased in on 1 January 2022 and is intended to encourage an even more rigorous assessment of long-tenured directors' independence in Singapore. ${ }^{127}$ According to the 2018 statistics of the Singapore Exchange Limited, more than eighty per cent of companies that had encountered corporate governance issues or material breaches of the SGX Listings Rules had controlling shareholders who were also directors or the chief executive officer of the company. ${ }^{128}$ Since it is crucial to maintain the independence of the boards of these companies, the two-tier vote to retain independent directors for longer than nine years, was formulated to specifically exclude from the vote shareholders who serve as directors or the chief executive officer of the company, and their associates. ${ }^{129}$ The two-tier vote is also intended to empower

125 This requirement is found in footnote 6 of the Singapore Code of Corporate Governance 2018 because it will only be phased in on 1 January 2022. This new requirement is based on SGX Listings Rules (Mainboard), r 210(5)(d)(iii) and SGX Listings Rules (Catalist), r 406(3)(d)(iii). Companies listed on the Singapore Exchange Limited (SGX) belong to companies listed either on the SGX Mainboard or SGX Catalist. A Mainboard listing is subject to review and approval by the SGX-ST (Singapore Exchange Securities Trading Limited) and the Monetary Authority of Singapore, while a Catalist listing is supervised and approved by an appointed sponsor.

126 See the definitions in the SGX Listings Rules (Mainboard) and the SGX Listings Rules (Catalist)).

127 It has been reported that the director with the longest tenure on the board of a listed company in Singapore was fifty-nine years, and that approximately forty-two per cent of companies listed in Singapore had at least one independent director who has served on the board for longer than nine years, see Angela Tan, 'Nine-year Cap on Independent Directors to Kick in from 2022' (The Business Times, 7 August 2018) <www.businesstimes.com.sg/government-economy/nine-year-cap-on-independentdirectors-to-kick-in-from-2022> accessed 16 April 2021).

128 See Corporate Governance Council, 'Response to Feedback received on Recommendations to the Corporate Governance Council' (6 August 2018) 13 <https://www.mas.gov.sg//media/MAS/Regulations-and-Financial-Stability/Regulatory-and-Supervisory-

Framework/Corporate-Governance-of-Listed-Companies/Consultation-2018-Jan-16/Response-toconsult/Response-paper-on-Councils-recommendations.pdf> accessed 20 April 2021.

129 ibid. 
shareholders to evaluate the independence of long-serving independent directors and to encourage active engagement by shareholders. ${ }^{130}$

\section{Hong Kong}

The Hong Kong Corporate Governance Code ('the HK CG Code') ${ }^{131}$ was also recently amended and took effect on 1 January 2019. Section A.4.3 of the HK CG Code expressly links director tenure to independence by stating that a term exceeding nine years could be relevant to determining the independence of a non-executive director. Section A.4.3 states further that if an independent non-executive director serves for longer than nine years, his or her further appointment should be approved by a special resolution of the shareholders. The special resolution must specify why the board believes that the director is still independent and should be re-elected. ${ }^{132}$ Since boards on Hong Kong companies are typically controlled by the founding family or dominated by a close-knit group of shareholders, ${ }^{133}$ a special resolution to approve the retention of an independent non-executive director for longer than nine years would give minority shareholders some say in this decision.

\section{India}

India is an example of another jurisdiction in which shareholder approval in the form of a special resolution is needed to approve an independent non-executive director's extended tenure. The Companies Act, 2013 ('India Companies Act') and the Securities and Exchange Board of India (Listing Obligations and Disclosure Requirements) Regulations 2015 ('LODR Regulations'), ${ }^{134}$ which came into force on 1 April 2019, are the main instruments of corporate governance practices of listed companies in India. The India Companies Act imposes obligations on companies to uphold corporate governance norms. Section 149(10) of the India Companies Act states that an independent director shall hold office for up to five consecutive years on the board of a company but shall be eligible for re-appointment on the passing of a special resolution by the company and the disclosure of such appointment by the board in its report. ${ }^{135}$ This provision is mandatory. An independent director may not hold office for more than two consecutive terms of five years but may be re-appointed as an independent director after a cooling-off period of three years if he or she was not, during those three years,

\section{0 ibid.}

131 The HK CG Code is set out in the Rules Governing the Listing of Securities on the Stock Exchange of Hong Kong Limited (Listing Rules), app 14. A 'comply or explain' approach is adopted (see HK CG Code, A14-2).

132 HK CG Code, s A.4.3.

133 See Lau (n 84) 308; Rajablu (n 82) 324 and Wai-ling (n 84) 5.

134 Securities and Exchange Board of India (Listing Obligations and Disclosure Requirements) Regulations 2015 [Last amended on 8 January 2021].

135 The board's report must be prepared in accordance with India Companies Act, s 134(3) and presented to the general meeting together with the financial statements. 
directly or indirectly appointed by or associated with the company in any other capacity. ${ }^{136}$

The high level of fraud experienced in companies in India highlighted the failure of the corporate governance structure in India, particularly in relation to independent directors, who were meant to bring objectivity to the board's oversight function. ${ }^{137}$ Therefore, the provisions relating to independent directors were considerably tightened up and incorporated into the India Companies Act in reaction to the extent to which corruption had infiltrated the economy and to ensure the 'independence' of independent directors on company boards. ${ }^{138}$ These provisions were implemented to: provide clarity on independent directors; affirm that independent directors are central to the functioning of a company without corruption and mismanagement; implement higher corporate governance standards in companies; and enhance the reputation and market value of companies. ${ }^{139}$ Significantly, these provisions give minority shareholders a voice in the election of independent directors, which is an important tool in companies in India where there is a concentrated shareholding with a controlling shareholder. ${ }^{140}$

From this survey of selected jurisdictions, the discussion now turns to recommendations for improving the regulation of director tenure in South Africa.

\section{Recommendations to Enhance the Regulation of Director Tenure in South Africa}

\section{Shareholder Approval}

South Africa's approach to director tenure is reflected in the third category discussed above: companies should take certain steps once director tenure exceeds a certain number of years. Thus, an independent non-executive director's tenure in excess of nine years, must be assessed every year and the board must disclose a summary of its views on the director's independence. ${ }^{141}$

As discussed earlier, the optimal director tenure varies from industry and company. It is submitted that a 'one-size-fits-all' approach would not be appropriate in South Africa because the types of activities and businesses conducted by companies are so diverse.

136 India Companies Act, s 149(11). The discretion given to reappoint the same director several times with a brief hiatus of three years in between, has been criticised (see for example Thej (n 43) 250-252).

137 Nayak (n 43) 104; Bala Balusubramanian, 'Strengthening Corporate Governance in India: A Review of Legislative and Regulatory Initiatives in 2013-2014' (2014) Working Paper No 447 of Indian Institute of Management Bangalore $24<\mathrm{https} / / / \mathrm{www} . i \mathrm{imb} . \mathrm{ac}$. in/sites/default/files/201807/WP_No._447_\%28Revised\%29_0.pdf> accessed 19 April 2021.

138 Nayak (n 43) 110.

139 Nayak (n 43) 109-110; Balusubramanian (n 137) 24 and 27.

140 Varottil (n 85) 357.

141 King IV Report, principle 7, recommended practices 29 and 30d. 
Imposing a mandatory term for independent non-executive directors would be tantamount to ignoring variations across different industries. It might also deprive companies of experienced directors' services and expertise. Moreover, the pool of qualified independent director candidates may be relatively small in certain specialised industries. For these reasons it is submitted that the King IV Report has commendably adopted a middle-ground approach to director tenure, and that a hard limit on director tenure (as set in France) should not be imposed.

South Africa's approach to directure tenure is similar to that adopted in the UK under the UK Corporate Governance Code for listed companies without a controlling shareholder. There is no maximum limit on the number of years that a board in South Africa or the UK may retain an independent non-executive director, provided that the board's views on the particular director's independence after he or she has served for nine years are disclosed to the shareholders. Despite these similarities, there are some differences. While the UK Guidance on Board Effectiveness encourages a board to discuss board refreshment with the company's shareholders, the King IV Report contains no equivalent recommendation. A further difference is that while shareholders in the UK are required by the FCA Listing Rules to approve, by way of a two-tier voting structure, the re-election of independent non-executive directors of listed companies with a controlling shareholder, there is no requirement under the JSE Listings Requirements to involve shareholders in decisions to retain independent non-executive directors.

It is submitted that South Africa's approach to director tenure reflects an inadequacy in that it overlooks the significance of giving shareholders a formal say in the decision whether to retain long-serving non-executive directors on the board after an extended period. South Africa should therefore augment its current recommendations in the King IV Report on director tenure by implementing a requirement that shareholders should approve the retention of independent non-executive directors after nine years. Since family-owned companies are not as prevalent in South Africa as in Malaysia, Singapore, Hong Kong and India, excluding the votes of controlling shareholders, shareholdingdirectors and their family members is not as important compared to those jurisdictions. For this reason, a two-tier voting process or shareholder approval by special resolution to approve the retention of long-serving independent non-executive directors, would not be appropriate in the South African context. It is submitted that an ordinary resolution of a simple majority of all shareholders to approve the retention of independent nonexecutive directors who have served on the board for longer than nine years would be appropriate in South Africa, and that a recommendation to this effect should be incorporated into the King IV Report.

The benefits of involving shareholders in the decision whether to retain long-serving independent directors are that it would encourage active shareholder engagement; afford shareholders an opportunity to assess any impairment in the objectivity of a long- 
serving independent director; amplify the reputation of companies and improve investor confidence. It would also serve to avoid a situation (for example, Comair as mentioned above), where shareholders at annual general meetings publicly challenge boards on their non-executive independent directors' extended tenure and may even pressurise those directors to resign.

\section{Full and Proper Disclosure to Shareholders}

The King IV Report states that when a non-executive director has served on the board for longer than nine years, a 'summary' of the board's views on his or her independence must be disclosed. ${ }^{142}$ It is submitted that this is a further weakness in the current system because a mere summary may not necessarily provide sufficient information to shareholders about the board's assessment of a director's independence. To alleviate shareholders' concerns over this independence, boards should provide more than a summary, and certainly more than a generic justification, of their views on this independence. In general, the detail of information to be disclosed by boards should be guided by considerations of materiality and should empower stakeholders to make an informed evaluation of the quality of the company's governance. ${ }^{143}$

The submission that boards should provide more than a summary of their views on a long-serving non-executive director's independence is supported by principle 6 , recommendation 1 of the King IV Report. This recommendation states that one of the ways in which the board should exercise its leadership role is by ensuring accountability for the company's performance by methods such as reporting and disclosure. The King IV Report places much emphasis on transparency and encourages board members to be transparent in how they discharge their governance role and responsibilities. ${ }^{144}$ This submission is further supported by section 7(d) of the Companies Act, which proclaims that one of the purposes of the Companies Act is to encourage transparency and high standards of corporate governance as appropriate, given the significant role of corporate enterprises within the social and economic life of the nation.

In the light of the emphasis on disclosure in the King IV Report, it is submitted that the board must disclose to shareholders:

- the type of the assessment performed to appraise the independence of the longserving non-executive director;

142 King IV Report, principle 7, recommended practice 30d.

143 King IV Report, Part 3: King IV Application and Disclosure at 37. The board has a discretion to decide where the disclosures should be made but the disclosures should be updated at least annually and should be publicly accessible (ibid 38).

144 King IV Report, principle 1, recommended practice 1f. 
- the result of the assessment; and

- the grounds for concluding that the director in question remains independent. ${ }^{145}$

For example, in disclosing the nature of the assessment performed, the board should disclose the documents it reviewed in performing the assessment, such as minutes of board meetings reflecting the director's voting actions.

\section{External Assessments of Non-Executive Independent Directors}

As mentioned earlier, under principle 7 , recommended practice 29 of the King IV Report, a non-executive director of the board may continue to serve in an independent capacity for longer than nine years if, upon an evaluation conducted by the board annually, it concludes that the director has exercised objective judgment, and that, when judged from the perspective of a reasonable and informed third party, there is no interest, position, association, or relationship which is likely to influence unduly or cause bias on decision-making. It is submitted that a further weakness in the current South African approach to director tenure is that the King IV Report does not recommend that this assessment should be conducted externally. It is submitted that to enhance objectivity, the King IV Report should strongly recommend that the board engage external, independent facilitators to assess the independence of a non-executive director after nine years. ${ }^{146}$

The drawbacks of the board itself evaluating the independence of a non-executive director after nine years are manifested in the Comair case, discussed above. Comair had initially defended the tenure of its long-serving non-executive directors by arguing that they were independent on the basis that a nomination committee had assessed their independence. ${ }^{147}$ The airline's shareholders rejected this argument because some of the long-serving non-executive directors on the Comair board had in fact served on the nomination committee, and could thus not validly conduct a review of their own independence. ${ }^{148}$ Had Comair been able to rely on an assessment conducted by an external facilitator, it might have been able to justify retaining its non-executive directors on its board for such lengthy periods.

145 See Malaysia Corporate Governance Guide (n 16) 86.

146 This requirement should apply primarily to listed public companies and to state-owned companies. Smaller, unlisted companies may be reluctant to engage external facilitators to assess the independence of a non-executive director after nine years due to the financial implications of an external assessment.

147 See Siseko Njobeni, 'New Comair Chair to Shake up Board' (Business Day, 30 October 2019) <https://www.pressreader.com/south-africa/business-day/20191030/281496458078286> accessed 16 April 2021.

148 ibid. 
External, independent facilitators must be involved in evaluating the independence of non-executive directors serving on the audit committee after nine years, ${ }^{149}$ because, in terms of section 94(4)(b) of the Companies Act, the directors serving on the audit committee must be independent non-executive directors. A company's audit committee is charged with several crucial tasks, such as:

- nominating persons to be appointed as the company's auditor;

- ensuring that any such nominee is independent of the company;

- receiving and dealing with any internal or external concerns relating to the company's auditor;

- making submissions on the company's accounting policies to the board; and

- performing any other oversight functions that the board may determine. ${ }^{150}$

In the light of these duties, it is imperative that audit committee members should remain independent and that their impartiality and objectivity should not be compromised. It is thus submitted that the independence of non-executive directors serving on the audit committee should be rigorously assessed after nine years, and that external facilitators must be involved in this assessment.

It is noteworthy that a new requirement introduced in the LODR Regulations in India, with effect from 1 April 2019, is that the assessment of independent non-executive directors must include an evaluation of the performance of the directors, and the fulfilment of the independence criteria (as specified in the LODR Regulations) ${ }^{151}$ and their independence from management. ${ }^{152}$ The King III Report similarly required an independent non-executive director's performance to be reviewed by the board after a nine-year tenure. ${ }^{153}$ Disappointingly, the King IV Report has done away with this recommendation.

Regarding the general performance evaluation process of board members, the King IV Report recommends that the evaluation process of directors may either be externally facilitated or not but must be conducted in accordance with a methodology approved by

149 As stated earlier, an audit committee must be appointed by a public company, a state-owned company, and any other company required by its memorandum of incorporation to have an audit committee (s 94(2) of the Companies Act).

150 See Companies Act, s 94(7) for a full list of the duties of the audit committee, and JSE Listings Requirements, para 3.84(g), which confers additional duties on the audit committees of listed companies.

151 See LODR Regulations, reg 16 for the independence criteria.

152 ibid reg 17(10).

153 King III Report, principle 2.18, recommended practice 77. 
the directors. ${ }^{154}$ The King IV Report permits a wide scope for the performance evaluations of directors to be conducted internally. In sharp contrast, the OECD Principles of Corporate Governance strongly recommend that the evaluation of board members should be supported by external facilitators to increase objectivity. ${ }^{155}$ The UK Corporate Governance Code similarly recommends, in provision 21, that the evaluation of the board of FTSE 350 companies ${ }^{156}$ should be externally facilitated, at least every three years. The Code recommends further that the external facilitator be identified in the annual report and a statement made about whether that person has any other connection with the company. ${ }^{157}$ In the UK Guidance on Board Effectiveness, the UK's Financial Reporting Council recommends that the board evaluation process 'should aim to be objective and rigorous, ${ }^{, 158}$ and that the board chairperson should ensure that the refreshment of the board is one of the considerations in the external valuation of the board. ${ }^{159}$ In Malaysia the MCCG 2021 also recommends that, for large companies, boards in Malaysia should engage independent experts to facilitate objective and unbiased board evaluations. ${ }^{160}$

Given the vital role played by independent non-executive directors on corporate boards, it is submitted that to enhance objectivity, the King IV Report should be revised to introduce a requirement that: the performance of independent non-executive directors should be evaluated every year, after such directors have served on the board for nine years in order to assess their independence; and external, independent facilitators should be involved in this evaluation.

As discussed earlier, an independent director should display both independence in appearance and independence of mind. ${ }^{161}$ A relevant consideration in assessing a longserving non-executive director's independence is whether he or she has developed any strong personal ties to management or a substantial shareholder over the years, which may influence his or her ability to act independently. ${ }^{162}$ Other factors are whether the director tends to defend policies and decisions that were previously supported but are

154 King IV Report, principle 9, recommended practice 73.

155 OECD Principles of Corporate Governance 53.

156 The FTSE 350 Index is a weighted stock market index based on the market price of the largest 350 companies which have their primary listing on the London Stock Exchange. It is a combination of the FTSE 100 Index of the largest 100 companies and the FTSE 250 Index of the next largest 250 companies.

157 UK Corporate Governance Code, provision 21.

158 UK Guidance on Board Effectiveness, para 106.

159 ibid, para 116.

160 MCCG 2021, practice 6.1. A large company is one on the FTSE Bursa Malaysia Top 100 index or companies with a market capitalisation of two billion Malaysian ringgit and above at the commencement of the company's financial year (see MCCG 2021 para 2.7).

161 King IV Report 28; Naidoo (n 6) 140; Malaysia Corporate Governance Guide (n 16) 82.

162 Malaysia Corporate Governance Guide (n 16) 86; ASX Corporate Governance Principles commentary to recommendation 2.3; Naidoo (n 6) 140-141. 
no longer appropriate, and fails to keep abreast of modern developments in the business environment. ${ }^{163} \mathrm{~A}$ further factor is whether the director remains passive during board deliberations, or shies away from asking challenging questions during board deliberations. ${ }^{164}$ In assessing a director's independence, it should also be considered whether he or she displays integrity, and is sufficiently confident to defend an independent viewpoint, adopt an unpopular stance, or disagree with other board members on matters. ${ }^{165}$ These suggestions offer guiding criteria that could be used to assess an independent director as they may indicate the likelihood of the director acting independently.

It is submitted that South African companies, having become aware of the controversy over the need to revise the practice regarding director tenure and noted the international trends towards setting limits and involving shareholders and independent, external experts, should take the initiative and examine whether, in the present circumstances of the company and its industry in South Africa, it should revise its memorandum of incorporation. In carrying out this task a board would be wise to seek the participation, views, and advice of the shareholders and of independent, external experts in corporate governance. If this careful examination reveals that the company rules and policies on director tenure need to be revised, the company can amend its memorandum of incorporation to limit the directors' term or provide for a staggered rotation of board members. ${ }^{166}$ Companies could go further to apply international best practices regarding the assessment of directors' independence and performance.

\section{Conclusion}

Director tenure is increasingly being recognised as a crucial factor in assessing the independence of a non-executive director. Independent directors play an important role in protecting shareholders' rights and interests and mitigating corporate corruption. Shareholder activists in South Africa are exerting pressure on long-serving directors to resign. The COVID-19 global pandemic has also highlighted the need for boards to be able to steer the company through testing circumstances and to appoint new nonexecutive independent directors with fresh perspectives and new expertise.

In this artice it is argued that the South African corporate governance approach to director tenure is flawed in three ways. First, it fails to give shareholders a formal say in retaining long-serving non-executive directors on the board beyond a period of nine years. Secondly, the board is required to disclose a mere summary of its views on the independence of a long-serving non-executive director to the shareholders, which might not provide them with sufficient information. Thirdly, the board need not engage any

163 See Malaysia Corporate Governance Guide (n 16) 86.

164 ibid 85-86.

165 ibid 85; Naidoo (n 6) 145.

166 Companies Act, s 68(1). 
external independent facilitators in assessing a non-executive director's independence or assess the latter's performance after nine years' board service has expired.

This article makes specific suggestions to overcome these weaknesses. First, it argued that, in line with the trend in international jurisdictions of involving shareholders in the decision whether to retain long-serving independent non-executive directors on the board, South Africa must consider revising its recommendations contained in the King IV Report to involve shareholders in the decision whether to extend the tenure of a nonexecutive independent director after nine years. It is submitted that an ordinary resolution of a simple majority of all shareholders to approve the retention of independent non-executive directors who have served on the board for longer than nine years would be appropriate. Secondly, boards must make a full and proper disclosure to shareholders of their reasons for considering long-tenured directors to be independent, instead of providing a mere summary of their views. Thirdly, external, independent facilitators must be involved in assessing so-called independent non-executive directors' independence after nine years. This requirement should apply primarily to listed public companies and state-owned companies. Fourthly, independent nonexecutive directors' performance should be evaluated every year after they have served for nine years to assess their independence, with external, independent facilitators being involved. This recommendation applies particularly to independent non-executive directors serving on the audit committee.

It is submitted that South Africa should review its corporate governance approach to director tenure in order to modernise and bring its corporate governance principles into line with international trends and developments. This review is essential in alleviating South African shareholder activists' growing concerns about certain directors' lengthy tenures in listed public companies. It is hoped that these suggestions will ensure that long-serving independent non-executive directors in South Africa remain independent. In the meantime, companies, working together with their shareholders, should take the initiative to examine their rules and practices on director tenure with the aid of independent, external experts on corporate governance and, if circumstances allow, amend their memorandums of incorporation to limit the directors' term or provide for a staggered rotation of board members. 


\section{References}

African Development Bank Group, 'African Economic Outlook 2020: Developing Africa's Workforce for the Future' (7 June 2019) <www.afdb.org/en/documents/african-economicoutlook-2020> accessed 19 April 2021.

Anderson A, 'Comair Chair Leaves Board After 46 Years' (Business Day, 9 January 2020)

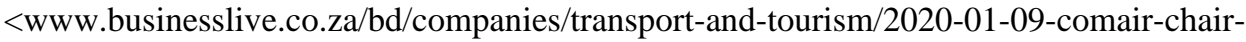
leaves-board-after-46-years/> accessed 16 April 2021.

Arindam M, 'The Independent Director: Has it been Indianised Enough?' (2013) 6(2) NUJS Law Review.

Balusubramanian B, 'Strengthening Corporate Governance in India: A Review of Legislative and Regulatory Initiatives in 2013-2014' (2014) Working Paper No 447 of Indian Institute of Management Bangalore 24 <https://www.iimb.ac.in/sites/default/files/201807/WP_No._447_\%28Revised\%29_0.pdf> accessed 19 April 2021.

Barker R and Chiu I, 'Protecting Minority Shareholders in Block-controlled Companies: Evaluating the UK's Enhanced Listing Regime in Comparison with Investor Protection Regimes in New York and Hong Kong' (2015) 10(1) Capital Markets Law Journal <https://doi.org/10.1093/cmlj/kmu031>

Cassim FHI, Cassim MF, Cassim R, Jooste R, Shev J and Yeats J, Contemporary Company Law (2nd edn, Juta 2012).

Cassim R, 'The Right of a Director to Participate in the Management of a Company: Kaimowitz v Delahunt 2017 (3) SA 201 (WCC)' (2018) 30(1) South African Mercantile Law Journal.

Chakraborty R, 'Singapore Acquires Top Ranking in Corporate Governance Globally' (Asia Insurance Review, 22 May 2019) <www.asiainsurancereview.com/News/ViewNewsLetter-Article/id/46863/Type/eDaily/Singapore-acquires-top-ranking-in-corporategovernance-globally\#> accessed 16 April 2021.

Chia Y, 'Board Diversity in Singapore' (2015) 27(2) Singapore Academy of Law Journal <https://doi.org/10.3850/S2345734115000186>

Davies P and Worthington S, Gower: Principles of Modern Company Law (10th edn, Sweet \& Maxwell 2016).

Donadelli M, Fasan M and Magnanelli B, 'The Agency Problem, Financial Performance and Corruption: Country, Industry and Firm Level Perspectives' (2014) 11 European Management Review <https://doi.org/10.1111/emre.12038> 
Duncan S, 'The Empirics of Governance and Fraud' (2009) 70(3) University of Pittsburgh Law Review.

Egan Associates, 'Director Tenure: How Long is too Long?' (16 May 2020) <https://eganassociates.com.au/board-tenure-how-long-is-too-long/?> accessed 15 April 2021.

Family Business Association of South Africa <https://fabasa.co.za/about/> accessed 19 April 2021.

FM Global, '2020 FM Global Resilience Index’ <https://www.fmglobal.com/research-andresources/tools-and-resources/resilienceindex> accessed 16 April 2021.

FM Global SG | Newsroom, 'High-Ranking Countries in 2020 FM Global Resilience Index Well Positioned to Foster Post-Pandemic Business Recovery’ (16 May 2020) $<$ https://newsroom.fmglobal.sg/releases/high-ranking-countries-in-2020-fm-globalresilience-index-well-positioned-to-foster-post-pandemic-business-recovery> accessed 16 April 2021.

Herlihy S, Stokdyk S and Trotter J, 'Director Tenure: A Solution in Search of a Problem' (2014) <www.lw.com/thoughtLeadership/lw-nacd-director-tenure> accessed 20 April 2021.

Hirsch R and Watson S, 'The Link between Corporate Governance and Corruption in New Zealand' (2010) 24 New Zealand Universities Law Review.

Hong T, 'Family-Owned Firms in Singapore: Legal Strategies for Constraining Self-Dealing in Concentrated Ownership Structures' (2011) 23 Singapore Academy of Law Journal.

Huang S and Hilary G, 'Zombie Board: Director Tenure and Firm Performance' (2018) 56(4) Journal of Accounting Research <https://doi.org/10.1111/1475-679X.12209>

Kalkoen D (ed), The Corporate Governance Review (10th edn, Law Business Research Ltd 2020).

Katz D and McIntosh L, 'Renewed Focus on Corporate Director Tenure' (2014) New York Law Journal (22 May 2014)

<www.wlrk.com/webdocs/wlrknew/AttorneyPubs/WLRK.23346.14.pdf> accessed 15 April 2021.

Koh J and Yip A, 'The Evolution of Corporate Governance in Singapore' (2016) <www.sid.org.sg//images/PDFS/Publications/BoardroomMatters/Vii/1.\%20Boardroom\%2 0Matters\%20Vol\%20IIThe\%20Evolution\%20Of\%20Corporate\%20Governance\%20In\%20Singapore.pdf> accessed 19 April 2021. 
Lau A, Nowland J and Young A, 'In Search of Good Governance for Asian Family Listed Companies; A Case Study on Hong Kong’ (2007) 28(10) Company Lawyer.

Libit W and Freier T, 'Director Tenure: The Next Boardroom Battle' (2015) The Corporate Board

<www.chapman.com/media/publication/498_Chapman_Director_Tenure_Next_Boardroo m_Battle_030415.pdf > accessed 20 April 2021.

Livnat J, Smith G, Suslava K and Tarlie M, 'Do Directors have a Use-by Date? Examining the Impact of Director Tenure on Firm Performance' (2019) 19(2) American Journal of Management <https://doi.org/10.1111/1475-679X.12209>

Mahlaka R, 'Comair Comes under Fire for Corporate Governance Mess' (Business Maverick, 16 January 2020) <www.dailymaverick.co.za/article/2020-01-16-comair-comes-underfire-for-corporate-governance-mess/.air> accessed 16 April 2021.

Manogna RL and Mishra AK, 'Exploring the Role of Family Ownership in Internationalization: Empirical Investigation of Indian Firms' (2021) 31(1) Review of International Business and Strategy <https://doi.org/10.1108/RIBS-05-2020-0058>

McCabe M and Nowak M, 'The Independent Director on the Board of Company Directors' (2008) 23(6) Managerial Auditing Journal <https://doi.org/10.1108/02686900810882101>

Naidoo R, Corporate Governance - An Essential Guide for South African Companies (3rd edn, LexisNexis 2016).

Nayak D, 'Role of Independent Directors - Is Section 149 better than Clause 149?' (2013) 2 National Law University Delhi Student Law Journal.

Nili Y, 'The "New Insiders": Rethinking Independent Directors' Tenure' (2016) 68(1) Hastings Law Journal.

Nili Y, 'Out of Sight, Out of Mind: The Case for Improving Director Independence Disclosure' (2017) 43(1) The Journal of Corporation Law.

Njobeni S, 'New Blood for Comair Board after Shareholder Outcry' (Business Day, 21 January 2020) <https://headtopics.com/za/new-blood-for-comair-board-after-shareholder-outcry10826996> accessed 16 April 2021.

Njobeni S, 'New Comair Chair to Shake up Board' (Business Day, 30 October 2019) <https://www.pressreader.com/south-africa/business-day/20191030/281496458078286> accessed 16 April 2021. 
Olano G, 'Singapore Tops Corporate Governance in FM Global Resilience Index' (Insurance Business Asia, 22 May 2019)

$<$ https://www.insurancebusinessmag.com/asia/news/breaking-news/singapore-topscorporate-governance-in-fm-global-resilience-index-167891.aspx $>$ accessed 16 April 2021.

Organisation for Economic Co-operation and Development, 'Business Insights on Emerging Markets (2020)' (OECD Emerging Markets Network, OECD Development Centre, Paris) <www.oecd.org/dev/EMnet-Business-Insights-2020.pdf> accessed 19 April 2021.

Petra S, 'Do Outside Independent Directors Strengthen Boards?' (2005) 5(1) Corporate Governance <https://doi.org/10.1108/14720700510583476>

PricewaterhouseCoopers, Non-executive Directors: Practices and Fees Trend Report (13th edn, 2020) (PWC, February 2020) <https://www.pwc.co.za/en/assets/pdf/ned-report2020.pdf $>$ accessed 19 April 2021.

Puchniak D and Luh LL, 'Independent Directors in Singapore: Puzzling Compliance requiring Explanation' (2017) 65(2) The American Journal of Comparative Law <https://doi.org/10.1093/ajcl/avx023>

Rajablu M 'Corporate Governance: A Conscious approach for Asia and Emerging Economies' (2016) 58(3) International Journal of Law and Management <https://doi.org/10.1108/IJLMA-04-2015-0017>

Razak MUA, Mahali M and Adam YC, 'Nine-year Tenure as Independent Director: Overstaying the Welcome?' (2016) 11(6) The Social Sciences.

Reddy B, 'The Fat Controller: Slimming down the Excesses of Controlling Shareholders in UK Listed Companies' (2018) 38(4) Oxford Journal of Legal Studies <https://doi.org/10.1093/ojls/gqy024>

Reguera-Alvarado N and Bravo F, 'The Effect of Independent Directors' Characteristics on Firm Performance: Tenure and Multiple Directorships' (2017) 41 Research in International Business and Finance <https://doi.org/10.1016/j.ribaf.2017.04.045>

Rosenblum D and Nili Y, 'Board Diversity by Term Limits' (2019) 71(1) Alabama Law Review.

Schipani C, 'The Role of Corporate Governance in Promoting Integrity and Addressing Corruption’ (2014) 35(5) Company Lawyer.

Securities Commission Malaysia, Corporate Governance Monitor 2020 (October 2020) <https://www.sc.com.my/api/documentms/download.ashx?id=ff69ce0d-a35e-44d4-996ac591529c56c7> accessed 15 April 2021. 
Securities Commission Malaysia, 'SC Updates the Malaysia Code on Corporate Governance to Promote Board Leadership and Oversight of Sustainability' (Media Releases, 28 April 2021) <https://www.sc.com.my/resources/media/media-release/sc-updates-the-malaysiancode-on-corporate-governance-to-promote-board-leadership-and-oversight-ofsustainability> accessed 2 May 2021 <https://doi.org/10.4324/9781003091622-3>

Singham K, 'Corporate Governance in Malysia' (2003) 15(1) Bond Law Review $<$ https://doi.org/10.53300/001c.5425>

Spencer Stuart, 2019 U.S. Spencer Stuart Board Index (Spencer Stuart, 2019) <https://www.spencerstuart.com/-/media/2019/ssbi-2019/us_board_index_2019.pdf> accessed 15 April 2021.

Spencer Stuart, 2019 UK Spencer Stuart Board Index (Spencer Stuart, 2019) <https://www.spencerstuart.com/-/media/2019/ukbi2019/uk_board_index_2019_final_version.pdf > accessed 15 April 2021.

Tan A, 'Nine-year Cap on Independent Directors to Kick in from 2022' (The Business Times, 7 August 2018) <www.businesstimes.com.sg/government-economy/nine-year-cap-onindependent-directors-to-kick-in-from-2022> accessed 16 April 2021.

Thej K, 'Independent directors in the Companies Act 2013: An Analysis' (2014) 35(8) Company Lawyer.

Tung F, 'The Puzzle of Independent Directors: New Learning' (2011) 91(3) Boston University Law Review.

Vafeas N, 'Length of Board Tenure and Outside Director Independence' (2003) 30(7)-(8) Journal of Business Finance and Accounting <https://doi.org/10.1111/1468-5957.05525>

Van Ness R, Miesing P and Kang J, 'Board of Director Composition and Financial Performance in a Sarbanes-Oxley World' (2010) 10(5) Academy of Business and Economics Journal.

Varottil U, 'Evolution and Effectiveness of Independent Directors in Indian Corporate Governance' (2010) 6 Hastings Business Law Journal.

Vaughn M and Ryan L, 'Corporate Governance in South Africa: A Bellwether for the Continent?' (2006) 14(5) Corporate Governance: An International Review <https://doi.org/10.1111/j.1467-8683.2006.00533.x>

Visser T and Chiloane-Tsoka E, 'An Exploration into Family Business and SMEs in South Africa' (2014) 12(4) Problems and Perspectives in Management.

Viviers S, 'Individual Shareholder Activism in South Africa: The Case of Theo Botha' (2016) 9(2) Journal of Economic and Financial Sciences <https://doi.org/10.4102/jef.v9i2.46> 
Viviers S, Mans-Kemp N, Luyt B and Cadle W, 'What Study Reveals About Board Independence at SA's Top Firms' (Business Day, 30 January 2020) <www.pressreader.com/south-africa/business-day/20200130/281895890220355> accessed 19 April 2021; also available at Suzette Viviers et al, 'News - Study Focuses on Board Independence at SA's Top Firms' (Stellenbosch University) <http://www.sun.ac.za/english/Lists/news/DispForm.aspx?ID=7068> accessed 19 April 2021.

Wai-ling C, Guide for Independent Non-Executive Directors' (6 edn, The Hong Kong Institute of Directors 2021).

Wiese T, Corporate Governance in South Africa with International Comparisons (2nd edn, Juta 2017).

Yeats JL, De la Harpe RA, Stoop H, Cassim R, Seligmann J, Kent L, Bradstreet RS, Williams RC, MF Cassim, Swanepoel E, Cassim FHI and Jarvis KA Commentary on the Companies Act of 2008 (Revision Service 1 2020, Juta 2018).

Cases

Fisheries Development Corporation of SA Ltd v Jorgensen; Fisheries Development Corporation of SA Ltd v AWJ Investments (Pty) Ltd 1980 (4) SA 156 (W).

Howard v Herrigel \& Another NNO 1991 (2) SA 660 (A).

Kaimowitz v Delahunt \& Others 2017 (3) SA 201 (WCC).

Protect a Partner (Pty) Ltd v Laura Machaba-Abiodun \& Others (2013) 34 ILJ 392 (LC).

Legislation, codes, guides, recommendations, and listing requirements

\section{Australia}

ASX Corporate Governance Council Corporate Governance Principles and Recommendations (4 edn, February 2019).

\section{European Union}

Official Journal of the European Union, 'Commission Recommendation of 15 February 2005 on the role of non-executive or supervisory directors of listed companies and on the committees of the (supervisory) board (2005/162/EC).'

\section{France}

Afep-Medef, 'Corporate Governance Code of Listed Corporations' (updated in January 2020). 


\section{Hong Kong}

Hong Kong Exchanges and Clearing Limited, 'Appendix 14: Corporate Governance Code and Corporate Governance Report.'

\section{India}

Companies Act, 2013.

Securities and Exchange Board of India (Listing Obligations and Disclosure Requirements) Regulations 2015 [Last amended on 8 January 2021].

\section{Malaysia}

Bursa Malaysia, Corporate Governance Guide Pull-out I: Guidance on Board Leadership and Effectiveness (3rd edn) <www.bursamalaysia.com/sites/5bb54be15f36ca0af339077a/assets/5bb54d165f36ca0c341 f0065/Pull-out_I.PDF> accessed 16 April 2021.

Securities Commission Malaysia, Malaysian Code on Corporate Governance 2012 (March 2012).

Securities Commission Malaysia, Malaysian Code on Corporate Governance (April 2017).

Securities Commission Malaysia, Malaysian Code on Corporate Governance (April 2021).

\section{Organisation for Economic Co-operation and Development}

Organisation for Economic Co-operation and Development, G20/OECD Principles of Corporate Governance (OECD Publishing 2015).

\section{Singapore}

Corporate Governance Council, 'Response to Feedback received on Recommendations to the Corporate Governance Council' (6 August 2018) 13 <https://www.mas.gov.sg//media/MAS/Regulations-and-Financial-Stability/Regulatory-and-SupervisoryFramework/Corporate-Governance-of-Listed-Companies/Consultation-2018-Jan16/Response-to-consult/Response-paper-on-Councils-recommendations.pdf > accessed 20 April 2021.

Singapore Exchange Limited, 'Code of Corporate Governance 2 May 2012.'

Singapore Exchange Limited, 'Code of Corporate Governance 2018.'

Singapore Exchange Limited Listings Rules (Catalist).

Singapore Exchange Limited Listings Rules (Mainboard). 


\section{South Africa}

Companies Act 71 of 2008.

Companies Regulations, 2011, published under Government Notice R351 (26 April 2011) GG 34239.

Institute of Directors South Africa, King Report on Governance for South Africa 2009 (2009).

Institute of Directors South Africa, King IV Report on Corporate Governance for South Africa 2016 (2016).

Johannesburg Stock Exchange Limited Listings Requirements.

\section{United Kingdom}

Financial Conduct Authority Listing Rules, Release 6 (April 2021).

Financial Reporting Council, UK Corporate Governance Code (July 2018).

Financial Reporting Council, Guidance on Board Effectiveness (July 2018).

\section{United States of America}

Institutional Shareholder Services Inc., United States Proxy Voting Guidelines: Benchmark Policy Recommendations Effective for Meetings on or after February 12020 (2019) <www.issgovernance.com/file/policy/active/americas/US-Voting-Guidelines.pdf> accessed 15 April 2021. 